Article

\title{
Chemically Surface Tunable Solubility Parameter for Controllable Drug Delivery-An Example and Perspective from Hollow PAA-Coated Magnetite Nanoparticles with R6G Model Drug
}

\author{
Quanguo $\mathrm{He}^{\dagger}{ }^{\dagger}$ Jun Liu ${ }^{\dagger}$, Jing Liang, Xiaopeng Liu, Du Tuo and Wen $\mathrm{Li}^{*}$ \\ School of Life Science and Chemistry, Hunan University of Technology, Zhuzhou 412007, China; \\ hequanguo@126.com (Q.H.); junliu@hut.edu.cn (Ju.L.); liangjingabbey@126.com (Ji.L.); \\ amituo321@163.com (X.L.); dutuo99@hut.edu.cn (D.T.) \\ * Correspondence: liwendream@163.com; Tel.: +86-0731-22183882 \\ + Those authors contributed equally to this work.
}

Received: 17 January 2018; Accepted: 5 February 2018; Published: 6 February 2018

\begin{abstract}
Solubility parameter-dependent drug releasing property is essential in practical drug delivery systems (DDS), and how to combine magnetic nanoparticles(NPs) and suitable polymer coating towards DDS is always a crucial and valuable challenge in biomedical application. Herein, a controllable drug delivery model with a surface having a chemically tunable solubility parameter is presented using hollow magnetite/polyacrylic acid $\left(\mathrm{Fe}_{3} \mathrm{O}_{4} / \mathrm{PAA}\right)$ nanocomposites as nanocarrier towards DDS. This composite is prepared by simply coating the modified hollow $\mathrm{Fe}_{3} \mathrm{O}_{4}$ with PAA. The coating amount of PAA onto the surface of $\mathrm{Fe}_{3} \mathrm{O}_{4}$ (measured by TGA) is about $40 \%(w / w)$. Then, Rhodamine 6G (R6G) is selected as model drug in drug delivery experiment. The efficiency of drug loading and drug release of these $\mathrm{Fe}_{3} \mathrm{O}_{4} / \mathrm{PAA}$ nanocarriers are evaluated under various temperature, solvent and $\mathrm{pH}$ values. As a result, the best drug releasing rate was achieved as $93.0 \%$ in $\mathrm{pH}=7.4$ PBS solution after $14 \mathrm{~h}$. The releasing efficiency is $86.5 \%$ in acidic condition, while a lower releasing rate $(30.0 \%)$ is obtained in aqueous solution, as different forms (polyacrylic acid and polyacrylate) of PAA present different solubility parameters, causing different salt and acid effects in various solvents, swelling property of PAA, and binding force between PAA and R6G. Therefore, by changing the solubility parameter of coating polymers, the drug delivery properties could be effectively tuned. These findings prove that the DDS based on magnetic particle cores and polymer encapsulation could efficiently regulate the drug delivery properties by tuning surface solubility parameter in potential cancer targeting and therapy.
\end{abstract}

Keywords: hollow $\mathrm{Fe}_{3} \mathrm{O}_{4}$ NPs; $\mathrm{Fe}_{3} \mathrm{O}_{4} /$ PAA composite NPs; solubility parameter; controlled release; drug delivery systems

\section{Introduction}

In recent decades, drug delivery system (DDS) based on nanomaterials has become an important potential method for cancer therapy in biomedical field. By combining the targeting and controlled drug release properties of these composite nanocarriers, the cancer therapeutic effect is improved because of the efficient utilization of these drugs with high concentration in cancer-related locus. The target property of nanocarriers is the prerequisite for delivering anti-cancer drug to desirable site in vivo. It could be realized by various methods, such as magnetic-guided targeting and specific ligands binding target (including antibody, polypeptide, sugar chain, and nucleic acid adapter). As one of the best magnetic materials, Magnetite $\left(\mathrm{Fe}_{3} \mathrm{O}_{4}\right)$ NPs are widely used in target DDS [1-3]. The magnetic property endows the nanocarriers with more specific targeting of cancer disease site under external 
magnetic field application. Interestingly, the $\mathrm{Fe}_{3} \mathrm{O}_{4} \mathrm{NPs}$ with internal mesoporous/hollow structures or with holes and cavities facilitate more drug loading for DDS. DDS applications of magnetic NPs requires not only the inherent magnetic performances improvement [4-7], but also their surface modification to enable multifunctional responses to various external changes [8-11]. Sensitive polymer modification is an effective alternative to overcome the above-mentioned problem; it enables the nanocarriers to act as multifunctional drug delivery carriers under different tumor circumstances [12,13]. These polymer-coated $\mathrm{Fe}_{3} \mathrm{O}_{4}$ NPs could improve the biocompatibility as well as control the drug release rate effectively. Moreover, different functional polymers could provide different controlled release mechanisms, such as $\mathrm{pH}$, temperature, chemical addition, or light triggered drug delivery systems [14]. For example, Zhao and co-workers synthesized a kind of yolk-shell magnetic composite NPs, which contained polymethacrylic acid (PMAA) coating and $\mathrm{Fe}_{3} \mathrm{O}_{4}$ NPs core. The composite NPs acted as a magnetic-pH response system. The in vitro model drug delivery of $\mathrm{Fe}_{3} \mathrm{O}_{4} / \mathrm{PMAA}^{\mathrm{NPS}}$ is also investigated with ceftriaxone sodium. The cavity of the yolk-shell structure could greatly improve the drug loading ability, and the polymer layer of PMAA could reduce the releasing rate under the acid condition [15].

However, for all these controlled releasing mechanisms, solubility parameter regulation is also important method according to the "like dissolves like" theory, and it is often ignored in DDS. Few investigations are focused on DDS using the principle of solubility parameter regulation of polymer coating. In our opinion, to attain controllable drug release, tunable solubility parameter surface in nanocarrier of DDS could be an ideal solution to address such a challenge. Generally, the drug releasing rate is directly determined by dissolvability of polymers and drugs in solvent. Good dissolvability in a solvent could improve the drug release rate. A similar solubility parameter of polymer, solvent or drugs promote the dissolvability of polymer and drugs in solvent [16,17]. Therefore, in the drug loading process, drugs could be dispersed uniformly in polymer as well as in the hollow inside structure of nanocarriers. Moreover, during drug release process, these polymers swell well in solvent, and drugs are easily released into solvent. Consequently, the drug release property could be regulated by the solubility parameter of coated polymers. However, few studies are focused on this influence of solubility parameter on drug delivery property. Polyacrylic acid (PAA) is a acidic polymer, which is usually used in biomedical field [18]. Moreover, PAA is a pH responsive polymer, and the $\mathrm{pH}$ values could affect the drug loading and releasing properties greatly. The main reason arises from different forms of PAA in solvent being able to induce different dissolvability of drug, and the stretch performance of PAA is a main factor in drug delivery process.

Herein, a drug delivery system example based on PAA coated hollow $\mathrm{Fe}_{3} \mathrm{O}_{4} \mathrm{NPs}$ is presented. The influence of solubility parameter changes of PAA on the alteration of drug loading and releasing properties is investigated, calculated and compared. The hollow structure of $\mathrm{Fe}_{3} \mathrm{O}_{4}$ is aimed for drug loading [4-7], and the PAA coating is presented as a controlled drug release material with chemically tunable solubility parameter. R6G is selected as model drug for loading and releasing investigations of these hollow $\mathrm{Fe}_{3} \mathrm{O}_{4} /$ PAA NPs. The influence factors for these drug loading and releasing performance are also investigated. Finally, the drug release mechanism based on the solubility parameter alteration of these hollow $\mathrm{Fe}_{3} \mathrm{O}_{4}$ /PAA NPs are discussed and compared carefully. In contrast with conventional pharmaceutical design and DDS design availability, the solubility parameter sets a fine example and offers a unique perspective for surface tunable polymer coating towards controllable DDS which is versatile for both hydrophilic and hydrophobic drugs with similar solubility parameter. Meanwhile, as a rough prototype, it will encourage and inspire more research efforts for practical solubility parameter-driven DDS.

\section{Material and Methods}

Ferric chloride hexahydrate $\left(\mathrm{FeCl}_{3} \cdot 6 \mathrm{H}_{2} \mathrm{O}\right)$, anhydrous sodium acetate (NaAc), ethylene glycol (EG), ethanol $(99.7 \%)$, sodium phosphate $\left(\mathrm{Na}_{2} \mathrm{HPO}_{4}\right)$, sodium dihydrogen phosphate $\left(\mathrm{NaH}_{2} \mathrm{PO}_{4}\right)$, sodium hydroxide $(\mathrm{NaOH})$, hydrogen chloride $(\mathrm{HCl})$ and other chemical reagents with analytical 
grade were purchased from Sinopharm Chemical Reagent Co. Ltd. (Shanghai, China) 3-ammonia propyltriethysilane (APTES), polyacrylic acid (PAA, WM 3000), 1-(3-Dimethylamino propyl)-3-ethyl carbodiimide hydrochloride (EDC.HCl), N-Hydroxy succinimide (NHS), and Rhodamine 6G (R6G) were purchased from Shanghai Aladdin Reagents Co. Ltd. (Shanghai, China). Millipore water $\left(18.2 \mathrm{M} \Omega \mathrm{cm}\right.$ at $\left.25^{\circ} \mathrm{C}\right)$ was used throughout all experiments.

Field emission Transmission electron microscopy (TEM) images were taken using a Hitachi JEM-1230 transmission electron microscope (JEOL, Tokyo, Japan) at an accelerating voltage of $200 \mathrm{kV}$. Scanning electron microscopy (SEM) images were obtained using a Hitachi S-3000 (Hitachi, Tokyo, Japan). X-ray powder diffraction (XRD) measurements were performed on a Bruker Advanced-D8 (Bruker AXS GmbH, Karlsruhe, Germany). Nanoparticle size analyzer patterns were taken at Malvern Zetasizer Nano S90 (Malvern, Worcestershire, UK). The HH-15 vibrating sample magnetometer (VSM) (Nanjing University Instrument Factory, Nanjing Institute of Electronics Ding one hundred) was used in the magnetic measurement. The FT-IR spectra were measured by FT-IR Spectrometer (Vector-22, Bruker Analytic GmbH, Hamburg, Germany). Thermogravimetric analyzer (TGA) (Q50, TA, New Castle, DE, USA) was used to measure the amount of coated PAA shell, Ultraviolet-visible spectrophotometer (UV-Vis) (T-1901, Purkinje General Corporation, Beijing, China).

\subsection{Synthesis of Hollow $\mathrm{Fe}_{3} \mathrm{O}_{4} \mathrm{NPS}$}

First, $5 \mathrm{mmol}$ of $\mathrm{FeCl}_{3} \cdot 6 \mathrm{H}_{2} \mathrm{O}$ were dissolved in $40 \mathrm{~mL}$ of EG to form a clear brown solution, and then $40 \mathrm{mmol}$ of anhydrous NaAc were added. The mixture was vigorously mixed by ultrasonication (10 $\mathrm{min}$ ) for formation of a homogeneous solution. Then, the solution was transferred into a Teflon-lined stainless steel autoclave $\left(100 \mathrm{~mL}\right.$ capacity) for hydrothermal treatment at $200{ }^{\circ} \mathrm{C}$ for $20 \mathrm{~h}$. After the autoclave was allowed to cool down to room temperature, the precipitate was collected by magnetic separation and washed by water and ethanol several times under sonication. Finally, the products were dried under vacuum at room temperature.

\subsection{The Surface Coating and Decoration of Hollow Magnetic Composite Particles}

Forty milligrams of $\mathrm{Fe}_{3} \mathrm{O}_{4}$ NPs were suspended into $100 \mathrm{~mL}$ of ethanol solution, and then $0.5 \mathrm{~mL}$ of APTES solution ethanol $(5 \% v / v)$ were added into the into above solution dropwisely. After several minutes, $1 \mathrm{~mL}$ of pure water was then added dropwisely. The mixture was stirred for $3 \mathrm{~h}$. The APTES-modified $\mathrm{Fe}_{3} \mathrm{O}_{4}$ NPs were collected by magnet, and washed by ethanol and deionized water three times, respectively. Then, $100 \mu \mathrm{L}$ of PAA solution was first added to another $5 \mathrm{~mL}$ of buffer solutions $(\mathrm{pH}=6.0)$ with $0.5 \mathrm{mmol} \mathrm{EDC} \cdot \mathrm{HCl}$ solutions. After this solution was sonicated for $10 \mathrm{~min}$, $0.5 \mathrm{mmol}$ of NHS solutions were added under ultrasound for another $30 \mathrm{~min}$. Ten milligrams of above APTES-modified $\mathrm{Fe}_{3} \mathrm{O}_{4}$ NPs were finally added under stirring for $4 \mathrm{~h}$. Finally, the precipitate was collected by magnetic separation and washed several times under sonication with water and ethanol and dried under vacuum at room temperature before characterization and application.

\subsection{The Preparation of Standard Curve of Rhodamine $6 \mathrm{G}$}

Rhodamine 6G (R6G) was used as simulative standard loading drug in this test. To obtain the relationship between concentration and absorbance, the standard curve determination of R6G was carried out. Specifically, $0.0072 \mathrm{~g}$ of R6G were dissolved into $1 \mathrm{~L}$ of pure water to form $0.15 \times 10^{-4} \mathrm{~mol} / \mathrm{L}$ of homogenous solution. Then, the prepared R6G solution was diluted to 5 precise concentration $\left(0.03,0.06,0.09,0.12\right.$, and $\left.0.15 \times 10^{-4} \mathrm{~mol} / \mathrm{L}\right)$ to acquire concentration gradients. The absorbances of above R6G solutions were determined by UV-Vis spectrometer at wavelength range of 200-700 nm. Consequently, the standard curve equation of the relationship between concentration and absorption was obtained. 


\subsection{Drug Loadings and Releasing Tests of $\mathrm{Fe}_{3} \mathrm{O}_{4} / \mathrm{PAA}$}

For the drug loading test of $\mathrm{Fe}_{3} \mathrm{O}_{4} / \mathrm{PAA}$ composite NPs, in typical process, $0.01 \mathrm{~g}$ of $\mathrm{Fe}_{3} \mathrm{O}_{4} / \mathrm{PAA}$ NPs were dispersed in $10 \mathrm{~mL}$ of phosphate buffered solution (PBS) by ultrasonication for $30 \mathrm{~min}$. Then, $10 \mathrm{~mL}$ of R6G solution $\left(1 \times 10^{-3} \mathrm{~mol} / \mathrm{L}\right)$ were added into the above suspension. In all cases, $\mathrm{Fe}_{3} \mathrm{O}_{4} /$ PAA composite NPs reached the adsorption equilibrium within $30 \mathrm{~min}$ at $30{ }^{\circ} \mathrm{C}$. After the magnetic separation of drug loaded $\mathrm{Fe}_{3} \mathrm{O}_{4}$ /PAA composite NPs, the supernatants were determined by UV-Vis spectrometer at $526 \mathrm{~nm}$ in the range of $200-700 \mathrm{~nm}$. Moreover, the absorption time, temperature, $\mathrm{pH}$ and concentration of $\mathrm{R} 6 \mathrm{G}$ are investigated to acquire the best drug loading amount.

The in vitro drug releasing test were conducted by using drug loaded $\mathrm{Fe}_{3} \mathrm{O}_{4} /$ PAA composite NPs under different $\mathrm{pH}$ environments. Typically, $0.01 \mathrm{~g}$ drug loaded $\mathrm{Fe}_{3} \mathrm{O}_{4} / \mathrm{PAA}$ composite NPs were dispersed into $100 \mathrm{~mL}$ of PBS. This solution was maintained at $37^{\circ} \mathrm{C}$ under slight shaking ( $50 \mathrm{rpm} / \mathrm{min}$ ). Then, the absorbance of supernatant was determined every $20 \mathrm{~min}$. As the release time increased, the sample intervals were prolonged to $40 \mathrm{~min}, 1 \mathrm{~h}$ and $2 \mathrm{~h}$ gradually. Thus, the drug releasing rates of these drug loaded $\mathrm{Fe}_{3} \mathrm{O}_{4}$ /PAA composite NPs were calculated accordingly.

\section{Result and Discussion}

\subsection{The Principle of the Preparation of $\mathrm{Fe}_{3} \mathrm{O}_{4} / \mathrm{PAA}$ Composite Magnetic NPS}

The hollow $\mathrm{Fe}_{3} \mathrm{O}_{4}$ NPs are coated with PAA to form the composite nanostructures by surface modification and chemical crosslinking reaction as depicted in Figure 1. Firstly, the surface of hollow $\mathrm{Fe}_{3} \mathrm{O}_{4}$ NPs are modified with amino group $\left(-\mathrm{NH}_{2}\right)$ terminal by using APTES as coupling agent. After hydrothermal reaction of magnetite formation, there are many hydroxyl $(-\mathrm{OH})$ groups present on the surface of $\mathrm{Fe}_{3} \mathrm{O}_{4}$ NPs. The hydrolytic reaction could initiate with these hydroxyl groups after APTES and water addition. The chemistry principle is shown in Figure 1 (Route 1). Then, the carboxyl $(-\mathrm{COOH})$ groups could be activated by EDC. $\mathrm{HCl}$ and NHS. The active $\mathrm{O}$-acylisourea intermediate is formed by firstly adding of EDC.HCl. However, the $\mathrm{O}$-acylisourea intermediate is unstable in aqueous solutions; its failure to react with an amine results in hydrolysis of the $\mathrm{O}$-acylisourea intermediate. The carboxyl is regenerated as a result, and an $N$-unsubstituted urea is released. Thus, the subsequently added NHS could replace the EDC. $\mathrm{HCl}$ rapidly, and the stable NHS-ester is formed. The specific route is shown in Figure 1 (Route 2). After adding the amino-modified $\mathrm{Fe}_{3} \mathrm{O}_{4} \mathrm{NPs}$, stable NHS-ester is easily displaced by nucleophilic attack from primary amino groups (from amino-modified $\mathrm{Fe}_{3} \mathrm{O}_{4} \mathrm{NPs}$ ) in the reaction mixture. Finally, the stable amide bonds are formed by combination of the primary amines and the original carboxyl groups (as shown in Figure 1 (Route 2)). Therefore, the PAAs are coated on the surface of hollow $\mathrm{Fe}_{3} \mathrm{O}_{4}$ NPs successfully.

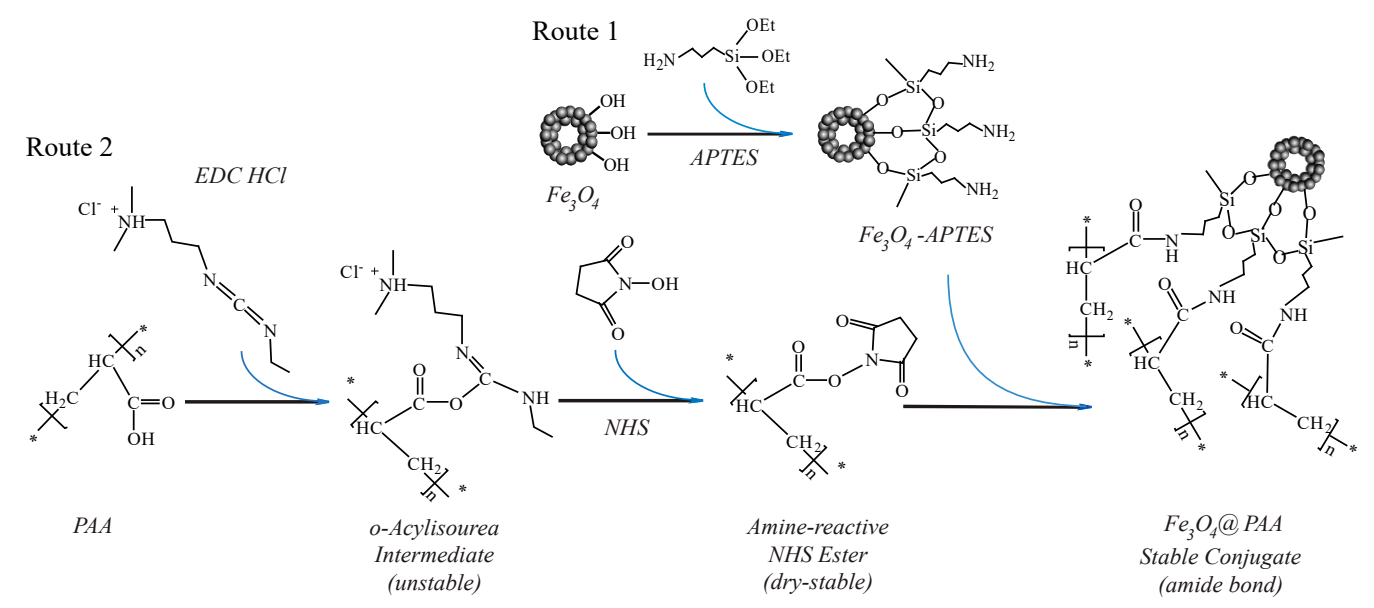

Figure 1. Schematic illustration of the process of $\mathrm{Fe}_{3} \mathrm{O}_{4} / \mathrm{PAA}$ composite magnetite hollow spheres formation. Abbreviations: $\mathrm{Fe}_{3} \mathrm{O}_{4} / \mathrm{PAA}$, PAA coated $\mathrm{Fe}_{3} \mathrm{O}_{4}$. 


\subsection{The Morphologies of the $\mathrm{Fe}_{3} \mathrm{O}_{4} / \mathrm{PAA}$ Composited NPS}

The morphologies of as-prepared hollow $\mathrm{Fe}_{3} \mathrm{O}_{4}$ NPs and $\mathrm{Fe}_{3} \mathrm{O}_{4} / \mathrm{PAA}$ composite NPs are characterized by SEM and TEM techniques. Figure 2A,B shows SEM images of hollow $\mathrm{Fe}_{3} \mathrm{O}_{4} \mathrm{NPs}_{\text {and }}$ $\mathrm{Fe}_{3} \mathrm{O}_{4}$ / PAA composite NPs, respectively. As shown in Figure 2A, the good dispersity of the hollow $\mathrm{Fe}_{3} \mathrm{O}_{4}$ NPs is presented. After coating with PAA shell, the dispersity of these $\mathrm{Fe}_{3} \mathrm{O}_{4} /$ PAA composite NPs becomes worse because the coated PAAs easily aggregate with each other. The insets are the size distribution of hollow $\mathrm{Fe}_{3} \mathrm{O}_{4}$ NPs and $\mathrm{Fe}_{3} \mathrm{O}_{4} /$ PAA NPs, and the average sizes are 236 and $291 \mathrm{~nm}$, respectively. After PAA coating, the average sizes of $\mathrm{Fe}_{3} \mathrm{O}_{4} / \mathrm{PAA} \mathrm{NPs}$ are enhanced, and the size distribution range is wider than for pure parent $\mathrm{Fe}_{3} \mathrm{O}_{4} \mathrm{NPs}$. Figure $2 \mathrm{C}$ is a TEM image of hollow $\mathrm{Fe}_{3} \mathrm{O}_{4}$ NPs. Evidently, these $\mathrm{Fe}_{3} \mathrm{O}_{4}$ NPs show the cavity structures under hydrothermal ripening process. After coating with PAA shell, the morphology of $\mathrm{Fe}_{3} \mathrm{O}_{4} /$ PAA composite NPs is different from the parent $\mathrm{Fe}_{3} \mathrm{O}_{4}$ NPs. The PAA adhesive layers are obviously characterized by smooth surface, and the hollow structure of internal $\mathrm{Fe}_{3} \mathrm{O}_{4}$ NPs becomes obscure (Figure 2D). Furthermore, the amplified TEM image of single $\mathrm{Fe}_{3} \mathrm{O}_{4}$ / PAA nanoparticle is presented in Figure 2E. The core-shell structure is more evident, and the hollow structure of $\mathrm{Fe}_{3} \mathrm{O}_{4}$ NPs could also be observed. These results indicate that the $\mathrm{Fe}_{3} \mathrm{O}_{4} /$ PAA composite NPs are synthesized successfully.
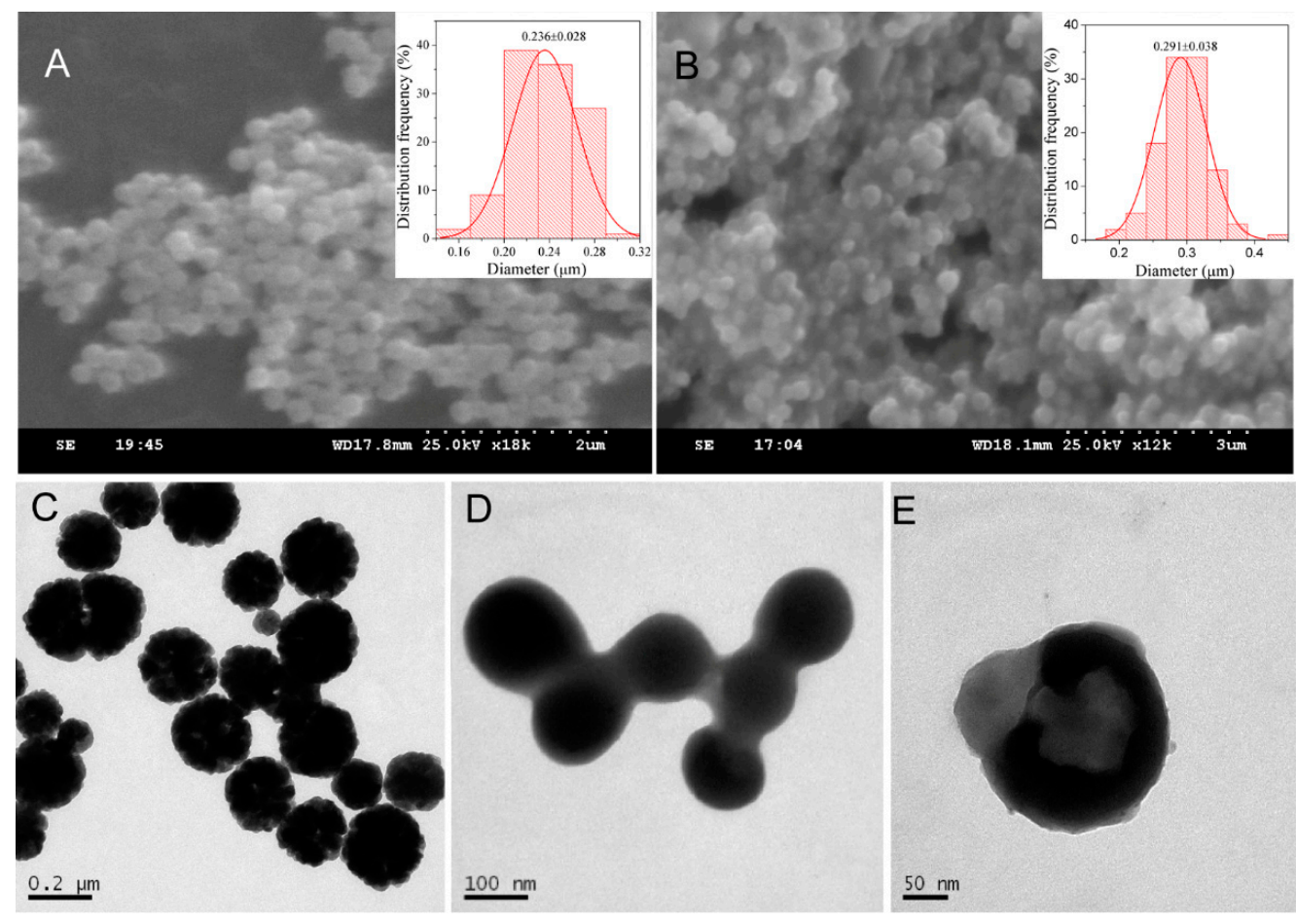

D

$\mathrm{E}$

Figure 2. SEM and TEM images of: $\mathrm{Fe}_{3} \mathrm{O}_{4}$ before coating $(\mathbf{A}, \mathbf{C})$; and $\mathrm{Fe}_{3} \mathrm{O}_{4} / \mathrm{PAA}$, after coating (B,D,E). Insets of $(\mathbf{A}, \mathbf{B})$ are their corresponding size distribution.

\subsection{The Structure and Element Analysis of the $\mathrm{Fe}_{3} \mathrm{O}_{4} / \mathrm{PAA}$ Composited NPS}

The crystal structures of these hollow $\mathrm{Fe}_{3} \mathrm{O}_{4} \mathrm{NPs}$ and $\mathrm{Fe}_{3} \mathrm{O}_{4} / \mathrm{PAA}$ composite NPs are also investigated by XRD. In Figure 3, curve (a) and curve (b) are the XRD patterns of hollow $\mathrm{Fe}_{3} \mathrm{O}_{4}$ NPs and $\mathrm{Fe}_{3} \mathrm{O}_{4} /$ PAA composite NPs, respectively. Moreover, the peak positions of XRD patterns in both two curves are almost the same, and the characteristic peaks located at $30.4^{\circ}, 35.7^{\circ}, 43.2^{\circ}, 53.7^{\circ}$, $57.3^{\circ}$ and $62.8^{\circ}$ could be indexed to (220), (311), (400), (400), (511) and (440) facets of inverse spinel magnetite (standard PDF Card NO. JSPDS 01-1111, $\alpha=8.393 \AA$ ), respectively. However, the intensity of these peaks for $\mathrm{Fe}_{3} \mathrm{O}_{4} /$ PAA composite NPs are lower than those of parent hollow $\mathrm{Fe}_{3} \mathrm{O}_{4} \mathrm{NPs}$, which indicates that the PAA coating could reduce the XRD intensity of hollow $\mathrm{Fe}_{3} \mathrm{O}_{4} \mathrm{NPs}$ effectively. 


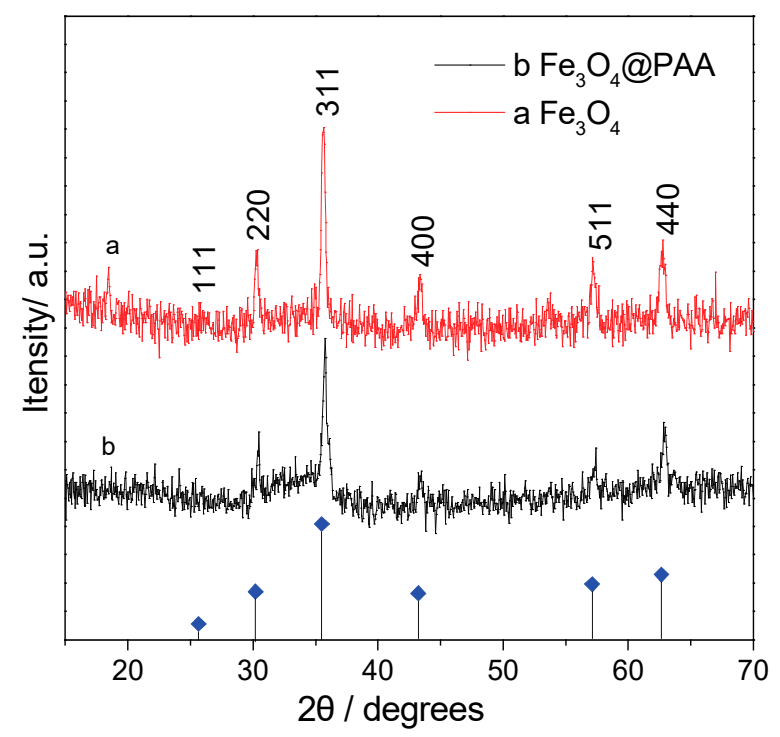

Figure 3. XRD patterns of: $\mathrm{Fe}_{3} \mathrm{O}_{4}(\mathbf{a})$; and $\mathrm{Fe}_{3} \mathrm{O}_{4} /$ PAA composite NPs (b).

Moreover, the element analysis of these samples is also investigated by EDX technique. Figure $4 \mathrm{~A}-\mathrm{C}$ shows the EDX spectra of hollow $\mathrm{Fe}_{3} \mathrm{O}_{4} \mathrm{NPs}$, APTES modified $\mathrm{Fe}_{3} \mathrm{O}_{4} \mathrm{NPs}$ and $\mathrm{Fe}_{3} \mathrm{O}_{4} / \mathrm{PAA}$ composite NPs, respectively. Obviously, in Figure 4A, Fe and O could be found in the EDX, and Na, $\mathrm{C}$ and $\mathrm{N}$ come from reactants, while $\mathrm{Al}$ is from the aluminum substrate. As shown in Figure $4 \mathrm{~B}$, after modification with APTES, Si emerges because of silane coupling agent of APTES. Moreover, this sharp peak of $\mathrm{Si}$ is decreased after PAA coating, as shown in Figure 4C. Meanwhile, $\mathrm{C}$ is enhanced in $\mathrm{Fe}_{3} \mathrm{O}_{4}$ /PAA composite NPs sample, which is probably due to the PAA polymer's coating, as it shields the inner core elements. All the above results indicate that the hollow $\mathrm{Fe}_{3} \mathrm{O}_{4} \mathrm{NPs}$ are coated by PAA shell to form a composite system as desired.
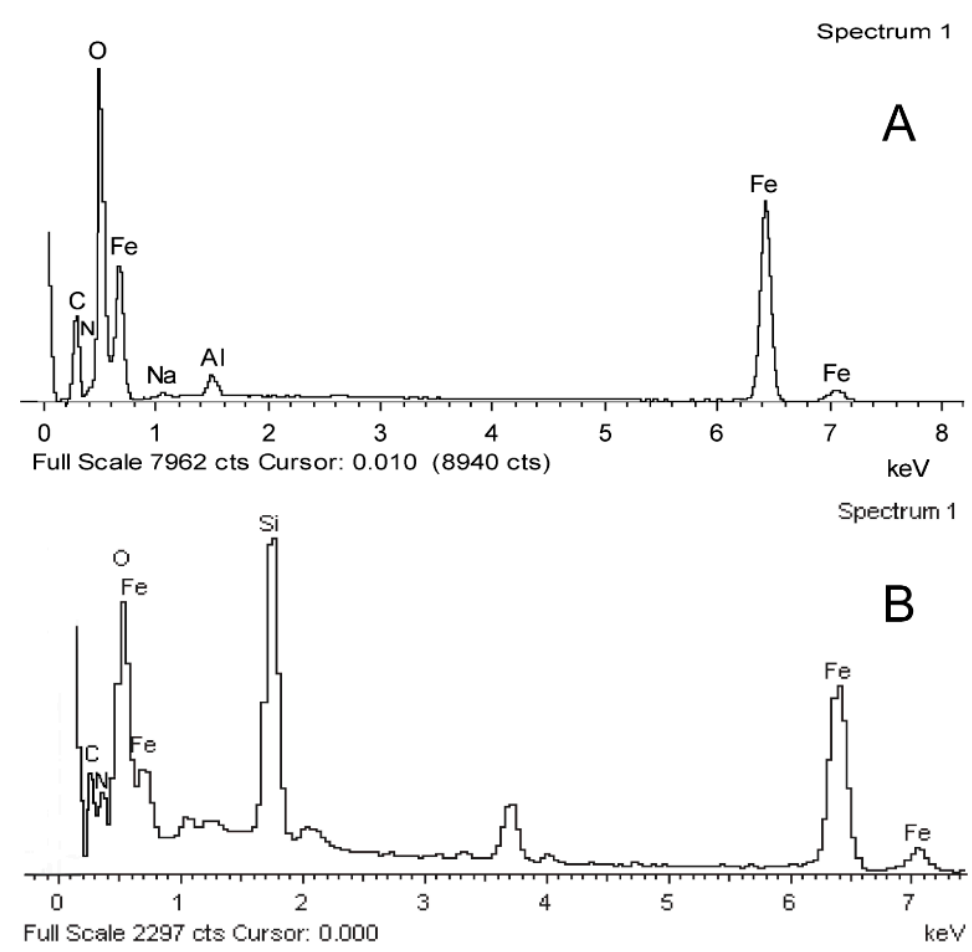

Figure 4. Cont. 


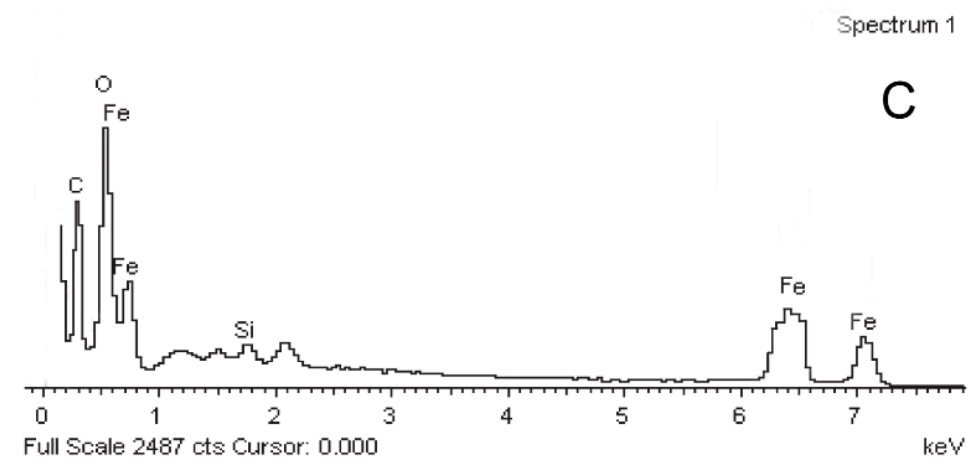

Figure 4. EDX patterns of: $\mathrm{Fe}_{3} \mathrm{O}_{4}$ (A); APTES-Fe $\mathrm{O}_{4}$ (B); and $\mathrm{Fe}_{3} \mathrm{O}_{4} /$ PAA composite NPs (C). Abbreviations: $\mathrm{Fe}_{3} \mathrm{O}_{4} /$ PAA, PAA coated $\mathrm{Fe}_{3} \mathrm{O}_{4}$; APTES- $\mathrm{Fe}_{3} \mathrm{O}_{4}$, (3-Aminopropyl)-triet-hoxysilane modified $\mathrm{Fe}_{3} \mathrm{O}_{4} ; \mathrm{EDX}$, energy dispersive $\mathrm{X}$-ray spectroscopy.

\subsection{The Magnetic Properties of the $\mathrm{Fe}_{3} \mathrm{O}_{4} / \mathrm{PAA}$ Composited NPS}

The magnetization curves of hollow $\mathrm{Fe}_{3} \mathrm{O}_{4}$ NPs and $\mathrm{Fe}_{3} \mathrm{O}_{4} /$ PAA composite NPs are shown in Figure 5A. The saturation magnetization values of hollow $\mathrm{Fe}_{3} \mathrm{O}_{4} \mathrm{NPs}$ and $\mathrm{Fe}_{3} \mathrm{O}_{4} / \mathrm{PAA}$ composite NPs are 125.0 (curve a) and 94.6 (curve b) emu/g, respectively. The present coercivity (Hc) values of both hollow $\mathrm{Fe}_{3} \mathrm{O}_{4}$ NPs and $\mathrm{Fe}_{3} \mathrm{O}_{4}$ /PAA composite NPs in Figure $5 \mathrm{~B}$ are less than $100 \mathrm{Oe}(\mathrm{A} / \mathrm{m})$, indicating their very good soft magnetism. In addition, as compared with that of the hollow $\mathrm{Fe}_{3} \mathrm{O}_{4}$ $\mathrm{NPs}$, the saturation of that PAA coating is decreased because the nonmagnetic PAA could reduce the weight of $\mathrm{Fe}_{3} \mathrm{O}_{4} \mathrm{NPs}$ per unit volume $[19,20]$. This result indicates that the PAA are successfully coated on the surface of magnetic NPs. Figure $5 \mathrm{C}$ shows photographs of the suspension of $\mathrm{Fe}_{3} \mathrm{O}_{4} \mathrm{NPs}$ and $\mathrm{Fe}_{3} \mathrm{O}_{4} /$ PAA composite NPs with and without of an external magnet contact. The nanospheres can easily disperse in ethanol solution to form a black suspension, and are drawn from the solution to the sidewall of the vial by an external magnetic field application within $1 \mathrm{~min}$. The magnetic particles can be brought again back into the original solution by removing the external magnetic field application and then slightly agitating. However, the adhesion time of $\mathrm{Fe}_{3} \mathrm{O}_{4} / \mathrm{PAA}$ composite NPs is prolonged compared to $\mathrm{Fe}_{3} \mathrm{O}_{4}$ NPs. It implies that the PAA coating weakens the magnetism of the parent cores of magnetite. This result is consistent with the magnetic characterization outcome.
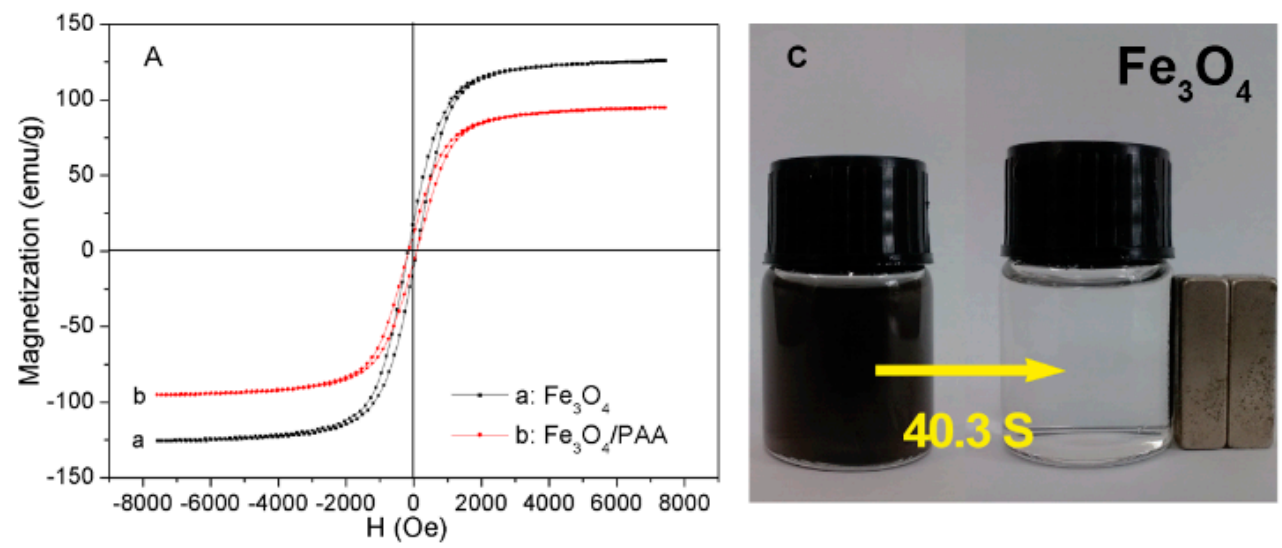

Figure 5. Cont. 

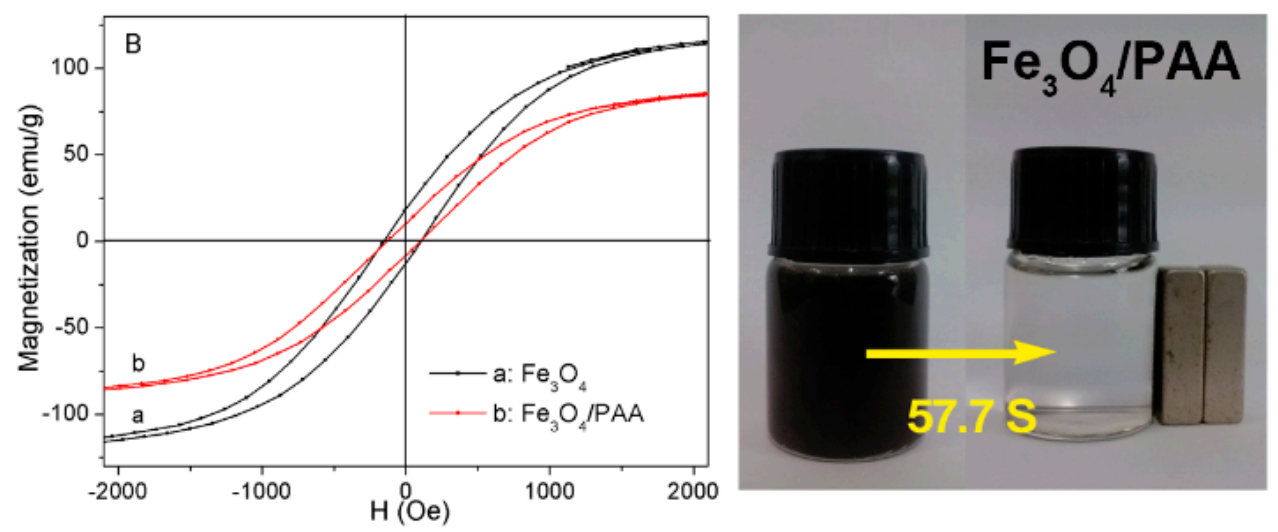

Figure 5. The hysteresis loops at $\mathrm{T}=300 \mathrm{~K}$ of: $\mathrm{Fe}_{3} \mathrm{O}_{4}$ (b) and $\mathrm{Fe}_{3} \mathrm{O}_{4} /$ PAA (a) (A); magnified part of the curves in (A,B); and photograph showing magnetic isolation $(\mathbf{C})$.

\subsection{The FT-IR Spectra of the $\mathrm{Fe}_{3} \mathrm{O}_{4} / \mathrm{PAA}$ Composited NPs}

The PAA coated hollow $\mathrm{Fe}_{3} \mathrm{O}_{4}$ NPs are further confirmed by Fourier transform infrared (FT-IR) spectra. The FT-IR spectra of hollow $\mathrm{Fe}_{3} \mathrm{O}_{4}$ NPs, APTES modified $\mathrm{Fe}_{3} \mathrm{O}_{4} \mathrm{NPs}, \mathrm{Fe}_{3} \mathrm{O}_{4} /$ PAA composite NPs and pure PAA are presented in Figure $6 \mathrm{a}-\mathrm{d}$. As shown in Figure 6a, the characteristic peak of $\mathrm{Fe}_{3} \mathrm{O}_{4} \mathrm{NPs}$ appears at $584.89 \mathrm{~cm}^{-1}$. In Figure $6 \mathrm{~b}$, after modification with APTES, the peaks at 1130, 1331.55 , and $1563.98 \mathrm{~cm}^{-1}$ are assigned to stretching vibration of Si-O, C-N and N-H, respectively. As compared with FT-IR spectra of pure $\mathrm{Fe}_{3} \mathrm{O}_{4}$ NPs, this result proves that APTES is modified on the surface of $\mathrm{Fe}_{3} \mathrm{O}_{4} \mathrm{NPs}$. Moreover, a very strong band emerges at around $1627.12 \mathrm{~cm}^{-1}$ in curve $\mathrm{c}$, which belongs to the stretching vibration of carbonyl $(-\mathrm{C}=\mathrm{O})$ bond in protonated carboxylate groups. This position is consistent with curve d (FT-IR spectra of pure PAA), indicating that the PAA exists in the $\mathrm{Fe}_{3} \mathrm{O}_{4} /$ PAA composite NPs.

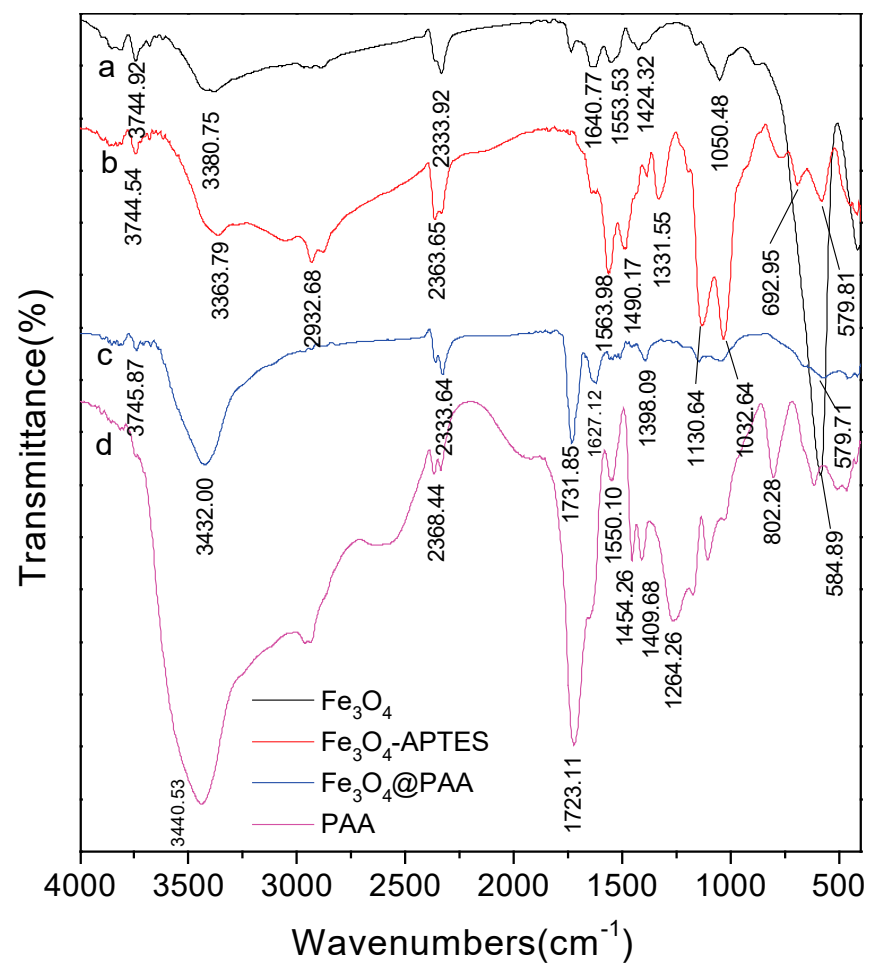

Figure 6. The FT-IR spectra of: bare $\mathrm{Fe}_{3} \mathrm{O}_{4} \mathrm{NPs}(\mathbf{a})$; APTES- $\mathrm{Fe}_{3} \mathrm{O}_{4}(\mathbf{b}) ; \mathrm{Fe}_{3} \mathrm{O}_{4} /$ PAA composite NPs (c); and PAA (d). 


\subsection{The Thermogravimetry of the $\mathrm{Fe}_{3} \mathrm{O}_{4} / \mathrm{PAA}$ Composited $\mathrm{NPS}$}

The TGA analysis of these as-prepared samples are presented for understanding the amount of the organic coatings. Figure 7a-c shows the TGA analysis of hollow $\mathrm{Fe}_{3} \mathrm{O}_{4} \mathrm{NPs}$, APTES modified $\mathrm{Fe}_{3} \mathrm{O}_{4}$ NPs and $\mathrm{Fe}_{3} \mathrm{O}_{4} /$ PAA composite NPs, respectively. Figure 7a shows the TGA curve of hollow $\mathrm{Fe}_{3} \mathrm{O}_{4} \mathrm{NPs}$, where about $5 \%$ of weight is lost after the temperature rises to $500{ }^{\circ} \mathrm{C}$. The lost could be attributed to the burning of organic groups on the surface of $\mathrm{Fe}_{3} \mathrm{O}_{4} \mathrm{NPs}$ and a little water evaporation. Figure $7 \mathrm{~b}$ shows the TGA curve of APTES modified hollow $\mathrm{Fe}_{3} \mathrm{O}_{4} \mathrm{NPs}$, where about $8 \%$ of weight is lost. The weight losses of these two steps are $2.8 \%$ and $4.9 \%$, respectively (the inset of Figure 7 ). A new weight losing step could be observed, which is ascribed to the loss of modified APTES shell. Figure 7c shows the TG curve of $\mathrm{Fe}_{3} \mathrm{O}_{4} /$ PAA composite NPs, where three weight loss steps are included. About $5.6 \%$ of weight is lost in Step 1, which begins at $50-60{ }^{\circ} \mathrm{C}$ and might be due to PAA being water adsorbing material, i.e., a lot of water is in the $\mathrm{Fe}_{3} \mathrm{O}_{4} / \mathrm{PAA}$ composite NPs. About 5.5\% of weight is lost in Step 2, which is almost the same as that in Figure 7b. Moreover, 25.2\% of weight is lost in Step 3, indicating that the organic materials (PAA) are lost with the raising of temperature. The ratio of PAA shell to hollow $\mathrm{Fe}_{3} \mathrm{O}_{4}$ NPs in this $\mathrm{Fe}_{3} \mathrm{O}_{4} / \mathrm{PAA}$ composite NPs could be calculated as follows: $25.2 \% /(100 \%-25.2 \%-6.2 \%-5.5 \%)$. About $40 \%(w / w)$ of PAA are coated onto the surface of hollow $\mathrm{Fe}_{3} \mathrm{O}_{4}$ NPs.

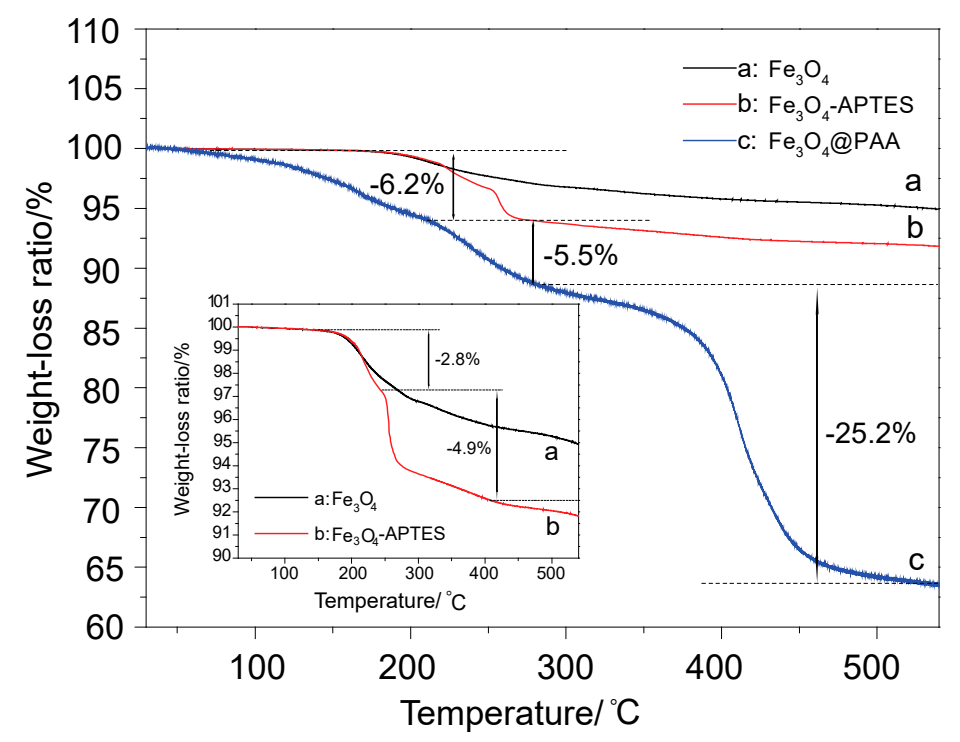

Figure 7. The thermogravimetric profile of: bare $\mathrm{Fe}_{3} \mathrm{O}_{4} \mathrm{NPs}(\mathbf{a})$; APTES- $\mathrm{Fe}_{3} \mathrm{O}_{4}$ (b); and $\mathrm{Fe}_{3} \mathrm{O}_{4} / \mathrm{PAA}$ composite NPs (c).

\subsection{Drug Loadings Tests of the $\mathrm{Fe}_{3} \mathrm{O}_{4} / \mathrm{PAA}$ Composited NPs}

Firstly, the standard linear equation of R6G is measured to obtain the relationship between concentration and absorbance (Figure 8A). R6G solution is used as the simulative drug for the drug loading and releasing test process, because R6G possess an amino hydrochloride salt structure (Figure 9A), and is highly similar to the molecular weight and surface groups of many anticancer drugs. After measuring the UV-visible spectra of R6G, the linear fitting is presented in Figure 8B, and the standard linear equation is calculated as follows: $A=7.80333 c+0.0301\left(R^{2}=0.99966\right.$, where $A$ is the absorbance and $\mathrm{c}$ is the concentration (unit: $\times 10^{-4} \mathrm{~mol} / \mathrm{L}$ )). Moreover, pure hollow $\mathrm{Fe}_{3} \mathrm{O}_{4} \mathrm{NPs}_{\mathrm{s}}$ and $\mathrm{Fe}_{3} \mathrm{O}_{4} /$ PAA composited NPs are used to adsorb and accommodate the R6G $\left(\mathrm{c}=0.15 \times 10^{-4} \mathrm{~mol} / \mathrm{L}\right)$ at room temperature. As shown in Figure 9B, the absorbance intensities decrease after adding pure hollow $\mathrm{Fe}_{3} \mathrm{O}_{4}$ NPs (curve b) and $\mathrm{Fe}_{3} \mathrm{O}_{4} /$ PAA composite NPs (curve c). After calculation, $1.00 \mathrm{~g}$ of unmodified hollow $\mathrm{Fe}_{3} \mathrm{O}_{4}$ NPs could adsorb $229.9 \mathrm{mg}$ of $\mathrm{R} 6 \mathrm{G}$, while $1.00 \mathrm{~g}$ of $\mathrm{Fe}_{3} \mathrm{O}_{4} /$ PAA composited NPs could adsorb $325.7 \mathrm{mg}$ R6G, greatly enhancing the model drug loading. These phenomena 
indicate that the hollow $\mathrm{Fe}_{3} \mathrm{O}_{4}$ NPs show the capacity of drug loading, and, after coating of PAA shell, the amount of drug loading is increased correspondingly.
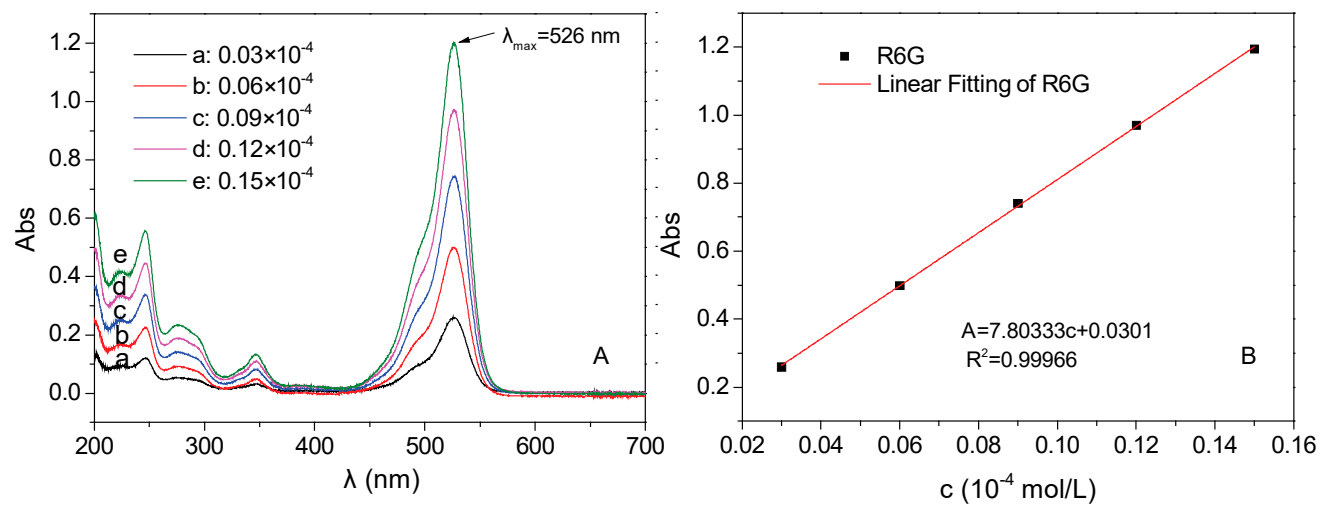

Figure 8. (A) UV-Vis spectra of the five groups of R6G with standard concentration $\left(\lambda_{\max }=526 \mathrm{~nm}\right)$; and (B): the linear fitting of R6G.
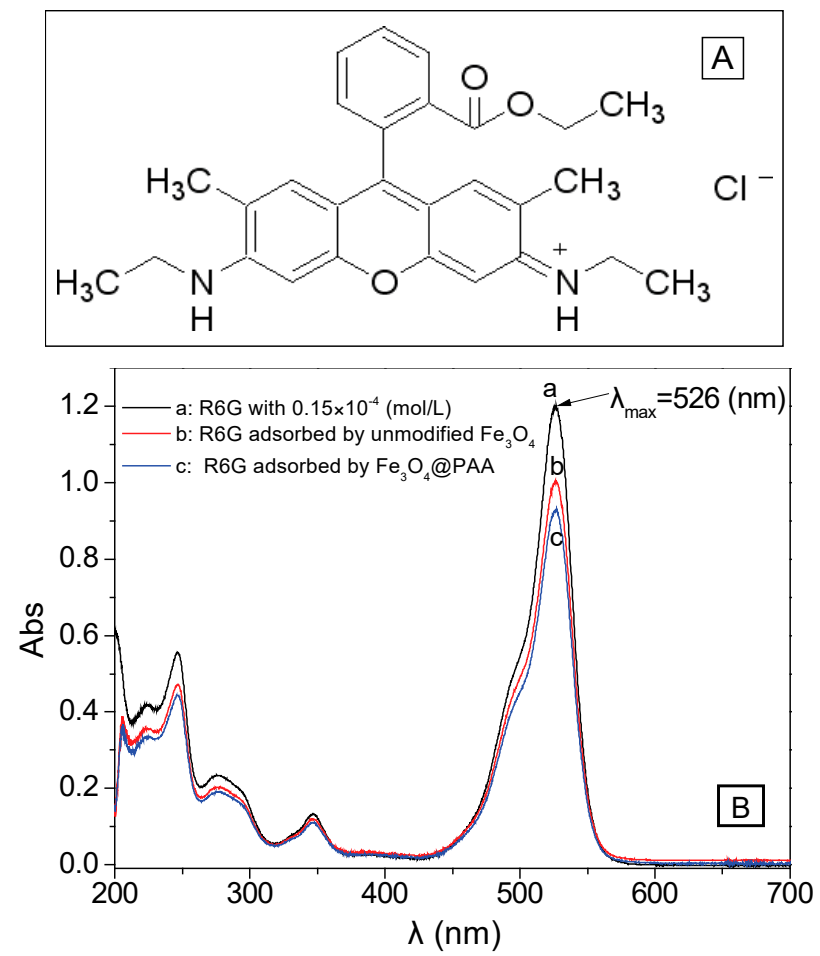

Figure 9. (A) Structure of R6G and (B) UV-Vis spectra of the three groups of R6G $\left(\lambda_{\max }=526 \mathrm{~nm}\right)$ : (a) absorbance of $0.15 \times 10^{-4} \mathrm{~mol} / \mathrm{L}$ of R6G; (b) absorbance of $\mathrm{R} 6 \mathrm{G}$ adsorbed by hollow $\mathrm{Fe}_{3} \mathrm{O}_{4}$; and (c) absorbance of $\mathrm{R} 6 \mathrm{G}$ adsorbed by $\mathrm{Fe}_{3} \mathrm{O}_{4} /$ PAA NPs.

\subsection{The Influence Factors for Adsorption Properties of the $\mathrm{Fe}_{3} \mathrm{O}_{4} / \mathrm{PAA}$ Composited NPS}

The drug loading conditions (temperature, time, $\mathrm{pH}$ and concentration of drugs) are investigated to obtain the best loading condition. Firstly, six different temperatures are compared to understand the influence of temperature on the amount of drug loading (other condition: the concentration of R6G is $0.15 \times 10^{-2} \mathrm{~mol} / \mathrm{L}$, mass of $\mathrm{Fe}_{3} \mathrm{O}_{4} /$ PAA composited NPs is $0.010 \mathrm{~g}$, $\mathrm{pH}$ is 7.4, and time is $30 \mathrm{~min}$ ). After the loading process, the adsorption performances of supernatants are presented in Figure 10A. The intensity order of these absorbances obtained at $526 \mathrm{~nm}$ is: $50^{\circ} \mathrm{C}>40^{\circ} \mathrm{C}>35^{\circ} \mathrm{C}>25^{\circ} \mathrm{C}>20^{\circ} \mathrm{C}$ $>30^{\circ} \mathrm{C}$. This result indicates that the largest absorbance is obtained under the temperature of $30^{\circ} \mathrm{C}$ 
because the intermolecular motion became fierce with the higher temperature. The best drug loading amount is $408.5 \mathrm{mg}$ of $\mathrm{R} 6 \mathrm{G}$ per $1.00 \mathrm{~g}$ of $\mathrm{Fe}_{3} \mathrm{O}_{4} / \mathrm{PAA}$ composited NPs, and the loading results are listed in Table 1.
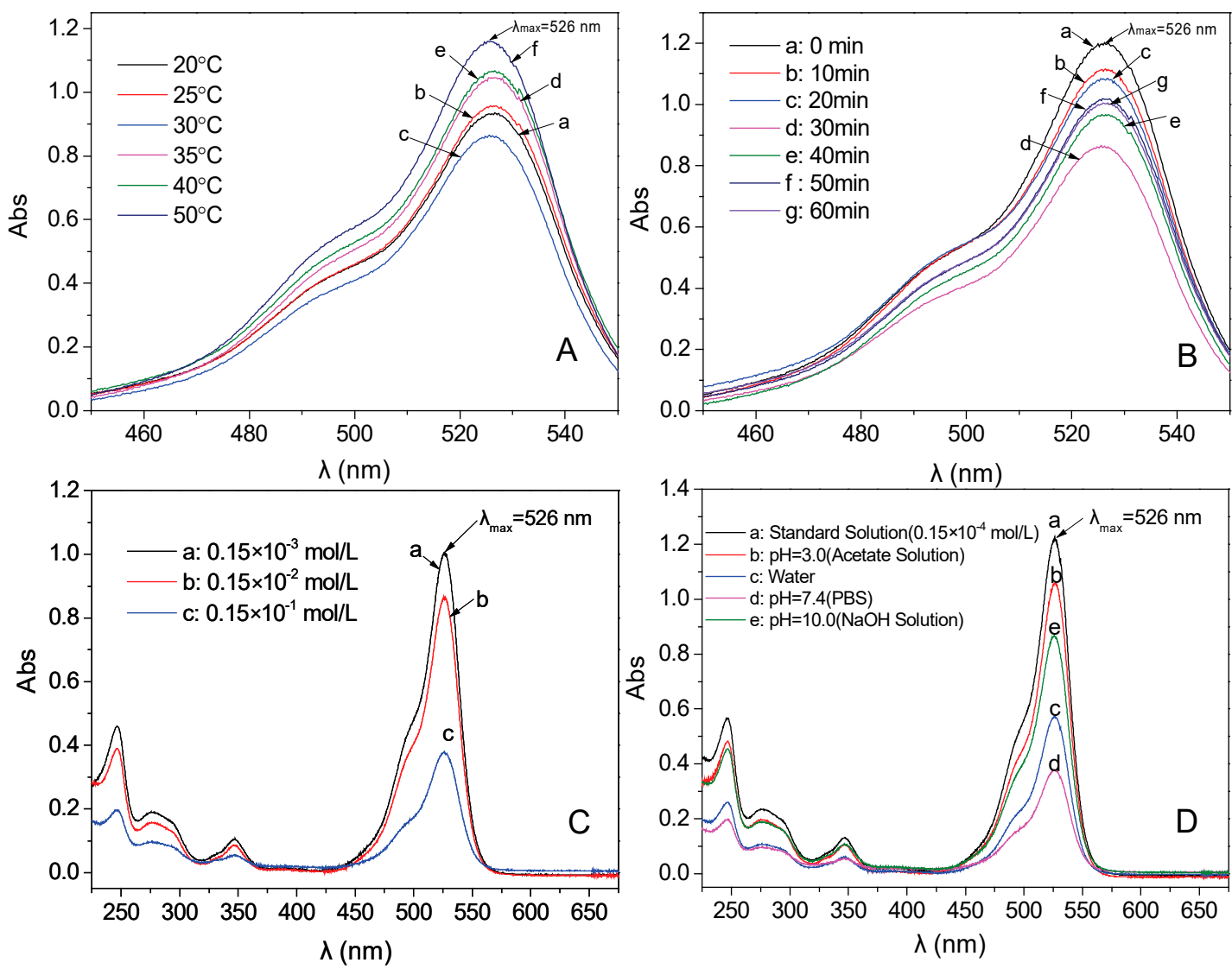

Figure 10. UV-Vis spectra of the supernatant after $\mathrm{R} 6 \mathrm{G}$ adsorbing with $\mathrm{Fe}_{3} \mathrm{O}_{4} / \mathrm{PAA}$ for different conditions $\left(\lambda_{\max }=526 \mathrm{~nm}\right)$ : (A) temperature; (B) adsorptive time; $(\mathbf{C})$ adsorptive concentration; and (D) $\mathrm{pH}$.

Table 1. The R6G loading capacity of $\mathrm{Fe}_{3} \mathrm{O}_{4} / \mathrm{PAA}$ magnetic particles at different temperature.

\begin{tabular}{ccccccc}
\hline Temperature $\left({ }^{\circ} \mathrm{C}\right)$ & $\mathbf{2 0}$ & $\mathbf{2 5}$ & $\mathbf{3 0}$ & $\mathbf{3 5}$ & $\mathbf{4 0}$ & $\mathbf{5 0}$ \\
\hline Absorbance & 0.926 & 0.955 & 0.860 & 1.046 & 1.064 & 1.159 \\
$\begin{array}{c}\text { Drug concentration }\left(\times 10^{-2} \mathrm{~mol} / \mathrm{L}\right) \\
\text { The remaining amount of R6G in } \\
\quad \text { 20 mL solution }(\mathrm{mg})\end{array}$ & 0.115 & 0.119 & 0.106 & 0.130 & 0.132 & 0.145 \\
$\begin{array}{c}\text { The amount of the adsorbed drug by } \\
\quad \text { 0.010 g particles }(\mathrm{mg})\end{array}$ & 3.257 & 2.919 & 4.085 & 1.802 & 1.581 & 0.414 \\
$\begin{array}{c}\text { The amount of the adsorbed drug by } \\
1.0 \text { g particles }(\mathrm{mg})\end{array}$ & 325.7 & 291.9 & 408.5 & 180.2 & 158.1 & 41.4 \\
\hline
\end{tabular}

Then, six different adsorption times are compared to investigate the influence of absorption time on the amount of drug loading. The best adsorption temperature $\left(30^{\circ} \mathrm{C}\right)$ is used in this experiment. Other conditions are kept the same to the process mentioned above. The intensity order of these absorbances at $526 \mathrm{~nm}$ is: $0 \mathrm{~min}>10 \mathrm{~min}>20 \mathrm{~min}>50 \mathrm{~min}>60 \mathrm{~min}>40 \mathrm{~min}>30 \mathrm{~min}$ (Figure 10B). It indicates that $30 \mathrm{~min}$ is the best adsorption time because the desorption effect also occurs when the adsorption time is prolonged. The drug loading amount is $408.5 \mathrm{mg}$ of $\mathrm{R} 6 \mathrm{G}$ per $1.00 \mathrm{~g}$ of $\mathrm{Fe}_{3} \mathrm{O}_{4} / \mathrm{PAA}$ composited NPs, and the test results are listed in Table 2. 
Table 2. The Rhodamine 6G (R6G) loading capacity of $\mathrm{Fe}_{3} \mathrm{O}_{4} /$ PAA magnetic particles at different adsorptive time.

\begin{tabular}{ccccccc}
\hline Adsorption Time (min) & $\mathbf{1 0}$ & $\mathbf{2 0}$ & $\mathbf{3 0}$ & $\mathbf{4 0}$ & $\mathbf{5 0}$ & $\mathbf{6 0}$ \\
\hline Absorbance & 1.109 & 1.083 & 0.860 & 0.964 & 1.018 & 1.006 \\
$\begin{array}{c}\text { Drug concentration }\left(\times 10^{-2} \mathrm{~mol} / \mathrm{L}\right) \\
\text { The remaining amount of R6G in }\end{array}$ & 0.138 & 0.135 & 0.106 & 0.120 & 0.127 & 0.125 \\
$\quad$ 20 mL solution (mg) & 13.246 & 12.927 & 10.189 & 11.466 & 12.129 & 11.981 \\
$\begin{array}{c}\text { The amount of the adsorbed drug by } \\
\quad \text { 0.010 g particles (mg) }\end{array}$ & 1.028 & 1.347 & 4.085 & 2.808 & 2.145 & 2.293 \\
$\begin{array}{c}\text { The amount of the adsorbed drug by } \\
\text { 1.0 g particles (mg) }\end{array}$ & 102.8 & 134.7 & 408.5 & 280.8 & 214.5 & 229.3 \\
\hline
\end{tabular}

Moreover, the different concentrations $\left(0.15 \times 10^{-3}, 0.15 \times 10^{-2}\right.$, and $\left.0.15 \times 10^{-1} \mathrm{~mol} / \mathrm{L}\right)$ of R6G solution are tested to investigate the influence of $\mathrm{R} 6 \mathrm{G}$ concentration on drug loading of $\mathrm{Fe}_{3} \mathrm{O}_{4} / \mathrm{PAA}$ composited NPs. Other experimental parameters are kept the same as the above experiment. As shown in Figure 10C, the amount of drug loading increases along with the improvement of the R6G concentration. However, the concentration could not enhance constantly, as the solubility is limited. Thus, the best concentration of R6G is $0.15 \times 10^{-1} \mathrm{~mol} / \mathrm{L}$. The detailed results are presented in Table 3 . The best drug loading amount is improved to $1011.1 \mathrm{mg}$ per $1.00 \mathrm{~g}$ of $\mathrm{Fe}_{3} \mathrm{O}_{4} / \mathrm{PAA}$ composited NPs.

Table 3. The Rhodamine 6G (R6G) loading capacity of $\mathrm{Fe}_{3} \mathrm{O}_{4} /$ PAA magnetic particles at different adsorptive concentration.

\begin{tabular}{cccc}
\hline Adsorption Concentration (mol/L) & $\mathbf{1 0}^{-\mathbf{3}}$ & $\mathbf{1 0}^{\mathbf{- 2}}$ & $\mathbf{1 0}^{\mathbf{- 1}}$ \\
\hline Absorbance & 1.004 & 0.860 & 0.377 \\
Drug concentration & $0.125 \times 10^{-3}$ & $0.106 \times 10^{-2}$ & $0.045 \times 10^{-1}$ \\
The remaining amount of R6G in 20 mL solution (mg) & 1.198 & 10.189 & 42.589 \\
The amount of added magnetic particles (g) & 0.001 & 0.01 & 0.1 \\
The amount of the adsorbed drug (mg) & 0.239 & 4.085 & 101.114 \\
The amount of the adsorbed drug by 1.0 g particles (mg) & 239.0 & 408.5 & 1011.1 \\
\hline
\end{tabular}

Finally, the environmental $\mathrm{pH}$ values are investigated to understand the influence of drug loading environment on the drug loading process. Four different $\mathrm{pH}$ conditions (acetic acid solution $(\mathrm{pH}=3.0)$, sodium hydroxide solution $(\mathrm{pH}=10.0)$, aqueous solution $(\mathrm{pH}=7.0)$ and PBS $(\mathrm{pH}=7.4)$ ) are carried out (Figure 10D). The best drug loading amount is obtained in PBS with $\mathrm{pH}=7.4$. Both low $\mathrm{pH}$ and high $\mathrm{pH}$ environment do not favor improving the drug loading of these NPs. The comparison results under different solvents are presented in Table 4.

Table 4. The R6G loading capacity of $\mathrm{Fe}_{3} \mathrm{O}_{4}$ / PAA magnetic particles at different $\mathrm{pH}$.

\begin{tabular}{ccccc}
\hline $\mathbf{p H}$ & $\begin{array}{c}\text { Acetic Acid } \\
\text { Solution } \mathbf{p H = 3 . 0}\end{array}$ & $\begin{array}{c}\text { Aqueous Solution } \\
\mathbf{p H}=\mathbf{7 . 0}\end{array}$ & $\begin{array}{c}\mathbf{P B S} \\
\mathbf{p H}=\mathbf{7 . 4}\end{array}$ & $\begin{array}{c}\mathbf{N a O H} \\
\mathbf{p H}=\mathbf{1 0 . 0}\end{array}$ \\
\hline $\begin{array}{c}\text { Absorbance } \\
\text { Drug concentration }\left(\times 10^{-1} \mathrm{~mol} / \mathrm{L}\right)\end{array}$ & 1.054 & 0.569 & 0.377 & 0.866 \\
$\begin{array}{c}\text { The remaining amount of R6G in } \\
\text { 20 mL solution }(\mathrm{mg})\end{array}$ & 0.131 & 0.069 & 0.045 & 0.107 \\
$\begin{array}{c}\text { The amount of the adsorbed drug } \\
\text { by 0.010 g particles (mg) }\end{array}$ & 125.501 & 66.103 & 42.589 & 102.508 \\
$\begin{array}{c}\text { The amount of the adsorbed drug } \\
\text { by 1.0 g particles }(\mathrm{mg})\end{array}$ & 18.202 & 77.600 & 101.114 & 41.195 \\
\hline
\end{tabular}




\subsection{In Vitro Release Properties of Rhodamine (R6G)}

Under optimum conditions, $0.100 \mathrm{~g} \mathrm{Fe}_{3} \mathrm{O}_{4} /$ PAA NPs are added into $40 \mathrm{~mL}$ phosphate buffer solution of R6G $\left(0.15 \times 10^{-1} \mathrm{~mol} / \mathrm{L}\right)$ for adsorption at $30^{\circ} \mathrm{C}$ for $30 \mathrm{~min}$, and then the absorbances of supernatant is measured by diluting them to $10^{-4}$ magnitude. As shown in Figure $11 \mathrm{~A}$, the absorbances of curves (a) and (b) are 1.177 and 0.291, respectively. After calculation, $10.0 \mathrm{mg}$ of drug loaded $\mathrm{Fe}_{3} \mathrm{O}_{4} /$ PAA NPs contain $6.851 \mathrm{mg}$ of R6G. Then, $0.010 \mathrm{~g}$ of drug loaded $\mathrm{Fe}_{3} \mathrm{O}_{4} /$ PAA composited NPs are dispersed into $100 \mathrm{~mL}$ of solution with varying $\mathrm{pH}$ values at temperature of $37^{\circ} \mathrm{C}$. The absorbances of supernatant are measured by UV-Vis spectra in a certain time interval. Drug release rate of these drug loaded $\mathrm{Fe}_{3} \mathrm{O}_{4} /$ PAA composited NPs under different $\mathrm{pH}$ condition are calculated and presented in Figure 11B. After releasing for $14 \mathrm{~h}$, the sample in PBS $(\mathrm{pH}=7.4)$ show the best drug release rate, about $93.0 \%$ of $\mathrm{R} 6 \mathrm{G}$ could be released into the PBS. In aqueous solution ( $\mathrm{pH}=7.0$ ), about $48.7 \%$ of $\mathrm{R} 6 \mathrm{G}$ are released in $14 \mathrm{~h}$. It is probably because R6G is a positively charged aqueous solution while carboxylic acid groups on the PAA molecular chains are dissociated to negative carboxylate anions, causing strong molecular electrostatic interactions between R6G and PAA. Therefore, loaded R6G could form ionic bonds with the carriers by the robust electrostatic attraction. Moreover, about $86.5 \%$ of the loaded $\mathrm{R} 6 \mathrm{G}$ are released within $14 \mathrm{~h}$ at $\mathrm{pH}=3.0$; because more protonated carboxyl groups exist, the R6G could be released from the carrier with the enhancement of the solubility of R6G under acidic conditions. However, in alkaline condition $(\mathrm{pH}=10.0)$, only about $30 \%$ of $\mathrm{R} 6 \mathrm{G}$ could be released. These results undoubtedly indicate that this drug delivery system composed of $\mathrm{Fe}_{3} \mathrm{O}_{4} / \mathrm{PAA}$ composited NPs shows a strong $\mathrm{pH}$ dependent releasing behavior of R6G. Therefore, as-designed $\mathrm{Fe}_{3} \mathrm{O}_{4} / \mathrm{PAA}$ composited NPs could potentially be used as drug delivery vehicles for cancer treatment. However, how can we understand such $\mathrm{pH}$ dependence and influence related to solvents in DDS? Many chemical and physical questions exist that need to be explored and answered.
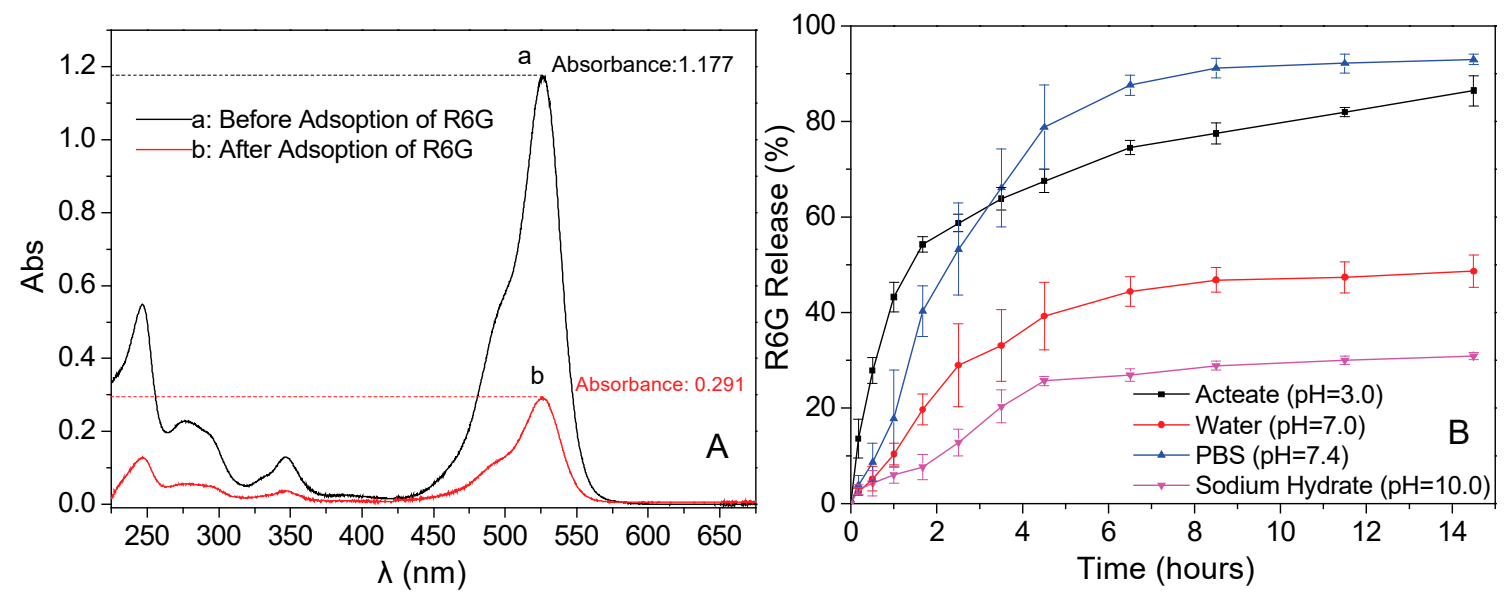

Figure 11. (A) UV-Vis spectra of the supernatant before and after absorbing with $\mathrm{Fe}_{3} \mathrm{O}_{4} / \mathrm{PAA}$ at optimum condition $\left(\lambda_{\max }=526 \mathrm{~nm}\right)$; and $(\mathrm{B})$ cumulative $\mathrm{R} 6 \mathrm{G}$ release $(\%)$ from $\mathrm{Fe}_{3} \mathrm{O}_{4} / \mathrm{PAA}$ composite NPs at different $\mathrm{pH}$.

\subsection{Release Mechanism of Rhodamine 6G (R6G)}

As the drug releasing results show, the release rate of $\mathrm{R} 6 \mathrm{G}$ is different under the various $\mathrm{pH}$ environments. The main reason of the phenomenon is proposed as the different solubility between PAA and solvent (or PAA and R6G). For the PAA and solvent, the PAA could be dissolved in the solvent when the solubility parameter of these two substances is the same. The water-solubility of PAA could be calculated using Equation (1), as proposed by P. A. Small [21].

$$
\delta=\frac{\sum F_{i}}{V}=\frac{\rho \sum F_{i}}{M}
$$


Here, $\delta$ is the Hansen solubility parameter, $V$ is the volume of polymer, and $\rho$ and $M$ are the density and molecular weight of the polymer repeating unit, respectively. $F_{i}$ is the molar attraction constant of a specific group $i$ according to Equation (1).

In neutral condition and acid condition, in term of PAA, $M=72.06, \rho=1.20 \mathrm{~g} / \mathrm{mL}$, and $\Sigma F_{i}=1399.83$, the solubility parameter of PAA can be calculated by above equation, i.e., $\delta=23.31\left(\mathrm{~J} / \mathrm{cm}^{2}\right)^{1 / 2}$. The solubility parameter of water is $23.40\left(\mathrm{~J} / \mathrm{cm}^{2}\right)^{1 / 2}$. It indicates that PAA exhibits good solubility in water because the two solubility parameters are almost identical. Moreover, in term of the model drug R6G, the solubility parameter is $21.77\left(\mathrm{~J} / \mathrm{cm}^{2}\right)^{1 / 2}$. This solubility parameter is also similar to that of water. Therefore, both R6G and PAA exhibit good solubility in water under neutral condition and acid condition. Meanwhile, R6G can be dissolved and dispersed in the PAA layer, and the swelling effect of PAA on water could promote both the loading and the releasing of R6G [22,23].

By comparison, in alkaline condition, PAA exists as a form of sodium polyacrylate, and $M=94.04$, $\rho=1.32 \mathrm{~g} / \mathrm{mL}, \Sigma F_{i}=1116.23$, and $\delta=15.67\left(\mathrm{~J} / \mathrm{cm}^{2}\right)^{1 / 2}$. It indicates that PAA shows a low solubility in water. This phenomenon leads to the PAA not being able to be stretched completely in water. Moreover, the solubility of R6G in PAA polymer become worse, and, consequently, the release rate of R6G is lowered evidently. Therefore, in experiment or practical application, R6G is selected as model drug for testing the drug released of $\mathrm{Fe}_{3} \mathrm{O}_{4}$ /PAA composite NPs, and services as a significant reference value in drug delivery application. Importantly, solubility parameter is ideal internal reference in DDS.

In Figure 11, we propose a diffusion-driven release dynamics mathematically for the $\mathrm{Fe}_{3} \mathrm{O}_{4} / \mathrm{PAA}$ composited NPs. The diffusion process of R6G follows the Fick's second law as Equation (2):

$$
\frac{\partial C_{i}}{\partial t}=\frac{D_{i p} \partial^{2} C_{i}}{\partial Z^{2}}
$$

Here, $C_{i}$ is the drug concentration, $t$ is time, $D_{i p}$ is the diffusion coefficient, and $Z$ is the position. During the diffusion process, the R6G inside the composite NPs is diffused to a position of its surface, and it can be considered as a kind of membrane diffusion. If $M_{t} / M_{\infty}<0.6$, the equation can be given as Equation (3):

$$
\frac{M_{i}}{M_{\infty}}=4\left(\frac{D_{i p} t}{\pi \delta}\right)^{1 / 2}
$$

Here, $M_{i}$ and $M_{\infty}$ denote the absolute cumulative amount of drug released at time $t$ and infinity, respectively. $\delta$ is the thickness of the polymer film. Equation (3) suggests that the relationship of release ratio $\left(M_{i} / M_{\infty}\right)$ and time is not linear. The drug releasing profile derived from the above equation is similar to the parabola in the first quadrant in Figure 11, which is consistent with the results of the experiments. This drug release process accords with the first order kinetics. Thus, the drug releasing process could be controlled to achieve a particular application in biotherapy by changing the morphology of composited NPs, the thickness of polymer layer and the concentration of drug loaded on the composited NPs.

\section{Conclusions}

In summary, PAA-coated hollow $\mathrm{Fe}_{3} \mathrm{O}_{4} \mathrm{NPs}$ are successfully synthesized to investigate the function of solubility parameter to drug delivery property. As a result, the coating amount of PAA onto the surface of $\mathrm{Fe}_{3} \mathrm{O}_{4}$ (measured by TGA) is about $40 \%(w / w)$. The best drug release rate was achieved as $93.0 \%$ in $\mathrm{pH}=7.4 \mathrm{PBS}$ solution after $14 \mathrm{~h}$. The release efficiency is $86.5 \%$ in acidic condition. Surficially, it seems that the salt effect and acid effect play significant roles in these two solvents, but it could not explain why a lower release rate (30.0\%) is obtained in aqueous solution. Essentially, different forms (polyacrylic acid and polyacrylate) of PAA under variable $\mathrm{pH}$ solvents could induce the different solubility parameter of nanocarriers, thus it tunes the coating polymer's surface solubility, which in turn controls the drug delivery performance of DDS. Moreover, the solubility parameter can also influence the swelling property of PAA, and binding force between PAA and R6G as well. 
This PAA-coated hollow magnetite DDS provides an example for selecting the solubility parameter as a determining factor in regulation of drug delivery properties, and offers an alternative for controllable DDS which is compatible with both hydrophilic and hydrophobic drug.

Acknowledgments: This work was supported by Key Program of Hunan Provincial Department of Science and Technology (2016NK2096), China of Postdoctoral Science Foundation (2016M592456), Hunan Provincial Natural Science Foundation, Doctoral construction program of Hunan University of Technology, Project of Science and Technology Department of Hunan Province, and Zhuzhou Science and Technology Plans (201707-201806).

Author Contributions: Quanguo He, Jun Liu and Wen Li conceived and designed the experiments; Jun Liu performed the experiments; Jun Liu, Jing Liang and Xiaopeng Liu analyzed the data; Quanguo He and Du Tuo contributed reagents/materials/analysis tools; Quanguo He and Jun Liu wrote the paper.

Conflicts of Interest: The authors declare no conflict of interest.

\section{References}

1. Xia, Y. Nanomaterials at work in biomedical research. Nat. Mater. 2008, 7, 758-760. [CrossRef] [PubMed]

2. Liu, J.; Huang, C.; He, Q. Pharmaceutical application of magnetic iron oxide nanoparticles. Sci. Adv. Mater. 2015, 7, 672-685. [CrossRef]

3. Douziech-Eyrolles, L.; Marchais, H.; Herve, K.; Munnier, E.; Soucé, M.; Linassier, C.; Dubois, P.; Chourpaet, I. Nanovectors for anticancer agents based on superparamagnetic iron oxide nanoparticles. Int. J. Nanomed. 2007, 2, 541-550.

4. Katsnelson, B.A.; Degtyareva, T.D.; Minigalieva, I.I.; Privaloca, L.I.; Kuzmin, S.V.; Yeremenko, O.S.; Kireyeva, E.P.; Sutunkoca, M.P.; Valamina, I.I.; Khodos, M.Y.; et al. Subchronic systemic toxicity and bioaccumulation of $\mathrm{Fe}_{3} \mathrm{O}_{4}$ nano-and microparticles following repeated intraperitoneal administration to rats. Int. J. Toxicol. 2011, 30, 59-68. [CrossRef] [PubMed]

5. Dorniani, D.; Hussein, M.Z.B.; Kura, A.U.; Fakurazi, S.; Shaari, A.H.; Ahmad, Z. Preparation of $\mathrm{Fe}_{3} \mathrm{O}_{4}$ magnetic nanoparticles coated with gallic acid for drug delivery. Int. J. Nanomed. 2012, 7, 5745-5756. [CrossRef] [PubMed]

6. Lin, X.; Zhao, S.; Zhang, L.; Hu, G.; Sun, Z.; Yang, W. Dose-dependent cytotoxicity and oxidative stress induced by "naked" $\mathrm{Fe}_{3} \mathrm{O}_{4}$ Nanoparticles in human hepatocyte. Chem. Res. Chin. Univ. 2012, 28, 114-118.

7. Jeng, H.A.; Swanson, J. Toxicity of metal oxide nanoparticles in mammalian cells. J. Environ. Sci. Health Part A 2006, 41, 2699-2711. [CrossRef] [PubMed]

8. Wang, J.; Chen, B.; Chen, J.; Cai, X.; Xia, G.; Liu, R.; Chen, P.; Zhang, Y.; Wang, X. Synthesis and antitumor efficacy of daunorubicin-loaded magnetic nanoparticles. Int. J. Nanomed. 2011, 6, 203-211.

9. He, Q.; Liu, J.; Huang, C.; Wu, Z. A nanoscale system for remarkably enhanced drug delivery based on hollow magnetic particles encapsulated within temperature-responsive poly (methylmethacrylate). Sci. Adv. Mater. 2014, 6, 387-398. [CrossRef]

10. Wahajuddin, S.A. Superparamagnetic iron oxide nanoparticles: Magnetic nanoplatforms as drug carriers. Int. J. Nanomed. 2012, 7, 3445-3471. [CrossRef] [PubMed]

11. Hussein-Al-Ali, S.H.; El Zowalaty, M.E.; Hussein, M.Z.; Ismail, M.; Webster, T.J. Synthesis, characterization, controlled release, and antibacterial studies of a novel streptomycin chitosan magnetic nanoantibiotic. Int. J. Nanomed. 2014, 9, 549-557.

12. Zhu, Y.; Ikoma, T.; Hanagata, N.; Kaskel, S. Rattle-type $\mathrm{Fe}_{3} \mathrm{O}_{4} @ \mathrm{SiO}_{2}$ hollow mesoporous spheres as carriers for drug delivery. Small 2010, 6, 471-478. [CrossRef] [PubMed]

13. Liu, T.Y.; Liu, K.H.; Liu, D.M.; Chen, S.Y.; Chen, I.W. Temperature-Sensitive Nanocapsules for Controlled Drug Release Caused by Magnetically Triggered Structural Disruption. Adv. Funct. Mater. 2009, 19, 616-623. [CrossRef]

14. Isojima, T.; Lattuada, M.; Vander Sande, J.B.; Hatton, T.A. Reversible clustering of pH-and temperatureresponsive Janus magnetic nanoparticles. ACS Nano 2008, 2, 1799-1806. [CrossRef] [PubMed]

15. Zhao, L.; Liu, H.; Wang, F.; Zeng, L. Design of yolk-shell $\mathrm{Fe}_{3} \mathrm{O}_{4} @$ PMAA composite microspheres for adsorption of metal ions and pH-controlled drug delivery. J. Mater. Chem. A. 2014, 2, 7065-7074. [CrossRef]

16. Belmares, M.; Blanco, M.; Goddard, W.A.; Ross, R.B.; Caldwell, G.; Chou, S.-H.; Pham, J.; Olofson, P.M.; Thomas, C. Hildebrand and Hansen solubility parameters from Molecular Dynamics with applications to electronic nose polymer sensors. J. Comput. Chem. 2004, 25, 1814-1826. [CrossRef] [PubMed] 
17. Hansen, C.M. Polymer science applied to biological problems: Prediction of cytotoxic drug interactions with DNA. Eur. Polym. J. 2008, 44, 2741-2748. [CrossRef]

18. Lu, M.Z.; Lan, H.L.; Wang, F.F.; Chang, S.J.; Wang, Y.J. Cell encapsulation with alginate and $\alpha$-phenoxycinnamylidene-acetylated poly(allylamine). Biotechnol. Bioeng. 2000, 70, 479-483. [CrossRef]

19. Daou, T.; Greneche, J.; Pourroy, G.; Buathong, S.; Derory, A.; Ulhaq-Bouillet, C.; Donnio, B.; Guillon, D.; Begin-Colin, S. Coupling agent effect on magnetic properties of functionalized magnetite-based nanoparticles. Chem. Mater. 2008, 20, 5869-5875. [CrossRef]

20. Vestal, C.R.; Zhang, Z.J. Synthesis and magnetic characterization of Mn and Co spinel ferrite-silica nanoparticles with tunable magnetic core. Nano Lett. 2003, 3, 1739-1743. [CrossRef]

21. Small, P. Some factors affecting the solubility of polymers. J. Appl. Chem. 1953, 3, 71-80. [CrossRef]

22. Angelatos, A.S.; Wang, Y.; Caruso, F. Probing the conformation of polyelectrolytes in mesoporous silica spheres. Langmuir 2008, 24, 4224-4230. [CrossRef] [PubMed]

23. Zhu, Y.; Shi, J.; Shen, W.; Dong, X.; Feng, J.; Ruan, M.; Li, Y. Stimuli-Responsive Controlled Drug Release from a Hollow Mesoporous Silica Sphere/Polyelectrolyte Multilayer Core-Shell Structure. Angew. Chem. 2005, 117, 5213-5217. [CrossRef]

(C) 2018 by the authors. Licensee MDPI, Basel, Switzerland. This article is an open access article distributed under the terms and conditions of the Creative Commons Attribution (CC BY) license (http:/ / creativecommons.org/licenses/by/4.0/). 